\title{
Alojz Gradnik, a Poet and Translator at the Linguistic, Cultural and Ideological Crossroads
}

\author{
ANA TOROŠ
}

\begin{abstract}
In the article I shall, on the example of the European poet and translator Alojz Gradnik (1882-1967), shed light on the impact of multiculturalism, multilingualism and ideological dichotomy on literary production and literary reception. Gradnik himself was in fact multicultural and multilingual, which was, however, unacceptable in his lifetime due to the specific social and political context. Gradnik thus gave up the multicultural and multilingual dimension. But due to this very element that he had denied himself, he was split within himself, which was reflected in his literary production; that is, in his poetry as well as in his translations of literary works. On the other hand, the image of Gradnik as a multicultural and multilingual author was exploited by the European totalitarianisms, therefore Gradnik as an author suffered a paradoxical fate.
\end{abstract}

Keywords: Alojz Gradnik, Slovenian poetry, multiculturalism, multilingualism, literary reception

\section{Gradnik's multicultural and multilingual environment}

Alojz Gradnik was one of the greatest Slovenian poets of the first half of the $20^{\text {th }}$ century. He appertained to the so-called Slovenian Modernism, which is known for the following authors - Ivan Cankar, Oton Župančič, Dragotin Kette and Josip Murn. His poetry thus shared some common traits with the dominant Slovenian literary trends of that period, while, on the other hand, it also diverged from them. According to certain literary historians, the reasons for Gradnik's unique poetic development are to be found precisely in his intercultural position (Župančič 1917: 47-49; Paternu 1955: 246; Zadravec 1999: 246), which I shall discuss in this paper.

Gradnik was born in the year 1882 in the village of Medana, located in the region called Goriška Brda, near the town of Gorica (It. Gorizia), on the present-day border between Slovenia and Italy. This is a hilly landscape, similar to the hills of Italy's Tuscany. It is dotted with little villages and churches sitting on the top of the hills, surrounded by vineyards, olive trees and fruit trees, among which cherry trees play a special role. The mild Mediterranean climate 
and the idyllic countryside, however, represent a contrast to the socio-national atmosphere of the region in the late $19^{\text {th }}$ century. In that period, Goriška Brda was a part of the Austro-Hungarian Empire, whose foundations had already been shaken. In the Gorizia region, which the town of Gorizia as well as Goriška Brda belonged to, the opposing voices of three large linguistic and cultural groups echoed - the Slavic, the Romance and the Germanic ${ }^{1}$ groups. $^{-}$ Gradnik belonged to all three of them.

Gradnik originated from a multinational family. His father, Jožef Gradnik, was Slovenian on his mother's side and he actually took over his mother's surname - Gradnik. Immediately after his birth, Jožef Gradnik was placed into foster care by his own mother, while he never came to know his father. He moved to Goriška Brda as an apprentice in the shoe-making business and at a later point he founded his own shoe-making workshop there (Boršnik 2008: 255-256). It was there that he met Alojz Gradnik's mother, Lucia Godeas. She was not Slovenian, but Friulian. She lived in the close proximity of Goriška Brda, where the hilly landscape meets the lowlands. This geographical boundary actually represented the border between the Slavic (Slovenian) and the Romance (Italian and Friulian) worlds (Marušič 2013: 117).

The Friulians form an ethnic group (Toplak 2011: 15-19) and the Friulian language belongs to the Romance language group. The Friulian identity has been growing stronger especially in the last decades. During Gradnik's lifetime, it was, however, not yet that clearly formed, therefore the Friulians identified themselves also with the neighbouring Italian nation (Kersevan 2003; Križman 2013). Accordingly, Gradnik felt he belonged to both of the two worlds, Italian and Friulian. But this identification with the Romance world only occurred at Gradnik's mature age.

Throughout his youth, Gradnik was in close contact with the Germanic (German and Austrian) culture, which was a consequence of living in the Austro-Hungarian Empire. As a ten-year-old boy, Gradnik had already moved to Gorizia, where he successfully continued schooling in the German language and graduated from a German grammar school. Later, he obtained a degree in law in Vienna. His educational environment had therefore always been German. He had a very good command of German and of the classical German literature. But despite this it seems that the young Gradnik, at least on a conscious level, kept a distance from the German (actually Austrian) culture. The reason for this may lie in the fact that Gradnik as a student, and later as a

The Slovenians as well as the Italians within the Austro-Hungarian Empire were striving to strengthen their own national identity, which lead to clashes between the Slovenians, Italians and the Austro-Hungarian Empire (Gabršček 1934). 
TOROŠ

young lawyer, did not favour the Austro-Hungarian Empire, which was clearly reflected in his poetry (Gradnik 1986: 45, 46).

Notwithstanding the above-mentioned fact, Gradnik could not avoid being influenced by the German culture. An example proving this is his fondness of the lyric poetry of the German poet Heinrich Heine (1797-1856), which he had secretly been reading already as a grammar school student and which he later translated (Boršnik 2008: 292; Toroš 2013a).

Up to the First World War, Gradnik did not question himself about his own national identity despite his multicultural and multilingual living environment. He felt he was Slovenian, he had adopted his father's Slovenian identity. He explained that his mother had learnt Slovenian after getting married. She is therefore said to have spoken to him only in Slovenian (Boršnik 2008: 260).

During his studies and in the years before the First World War, Gradnik was politically engaged in actions to unite the Slovenians with other South Slavic nations to form a common state (Boršnik 2008: 342). ${ }^{2}$ He thus began to identify himself with the wider, Slavic community as well.

The key turning point in Gradnik's perception of his own identity, despite the facts described, came as late as in the turbulent years of the AustroHungarian Empire falling apart, amid the terror of the First World War and the emerging fascism, when Gradnik was approximately thirty years old.

During the First World War, the Kingdom of Italy occupied Gradnik's native Gorizia region and soon after the end of the war the systematic and violent suppression of the Slovenians in this area began (Čermelj 1965; Kacin Wohinz 2000). As a result, Gradnik's response to the Italian nation was at first negative. At the same time we should take into account the fact that Gradnik knew and assessed this nation merely on the basis of their fascist activities. The Italian culture and literature were alien to him; according to his words, he consciously rejected them because of the tense situation between the Slovenian and the Italian nations in the Gorizia region (Boršnik 2008: 292). But during this very period in which Gradnik was fighting fiercely for the Slovenian and Yugoslav state and rejecting everything Austrian as well as Italian, he came across the novel Zwischen den Rassen by the German writer Heinrich Mann. Among the Slovenians, Heinrich Mann, a brother of the more famous writer Thomas Mann, was at that time well-known for his novels with socio-critical and anti-nationalistic content. His novel Zwischen den Rassen, however, remained more or less overlooked. After all, this novel might not

After the First World War the State of Slovenians, Croats and Serbs, at a later point renamed to the Kingdom of Serbs, Croats and Slovenians; and further on to the Kingdom of Yugoslavia. 
have ended in Gradnik's hands by chance, as Gradnik was highly educated and deeply reasoning and as such he must have secretly been questioning the heritage of his mother's culture. After the Second World War he explained that this novel "made him think a lot" (Boršnik 2008: 428). The novel actually depicts the inner turmoil within its main heroine descending from a nationally mixed family, Romance on her mother's side and Germanic on her father's side. Throughout the novel, its heroine seeks her true identity and balance, but the harmony of the two opposing poles within her inner self cannot be achieved. She thus feels different, somehow hovering between the two cultures. Her peculiarities are, for instance, reflected in her language, habits and her physical appearance (Toroš 2013a).

While reading the above-mentioned novel, Gradnik most likely began to think about the overlooked side of his cultural heritage he had inherited from his mother. How to match his own image of the Italian nation as a fascist nation and the image of the nation from which he had partly descended? The two nations he descended from on his mother's and, on the other hand, on father's side were hostile to each other. The historical context in which Gradnik had been placed demanded the unequivocal taking of either one or the other side. The complete acceptance of one culture and the rejection of the other.

This incongruence of Gradnik's true perception of his double national identity was reflected in his poetry. In his second collection of poems Pot bolesti (The Path of Sorrow, 1922) he actually adopted a strong standpoint towards the Italian nation in the Gorizia region. The lyric subject of his poems is usually a first-person plural subject speaking on behalf of the Slovenians in this region. In these poems, Gradnik undoubtedly identifies himself with the Slovenian community. The image of the Italians in the poems is, on the other hand, that of the antagonists, in terms of morals they are presented as significantly negative characters, who by all means wish to humiliate the dignity of the Slovenians and eventually assimilate them in a violent manner, expel them from the Gorizia area or put them to death. The publication of Gradnik's third collection of poems De profundis (1926) brings a change in Gradnik's image of the Italians. The Italians only appear in one poem within the collection, in the sonnet called "Vprašanje" ("Question") (Gradnik 1986: 183). Concerning its content, the sonnet is not special only within Gradnik's opus, but also represents a unique example within the contemporary Slovenian poetry, as it was written and published in the period of the fascist suppression of the Slovenians, that means at the time when the Slovenian poetry more or less followed the above-described poetic scheme, that of cruel Italians, tyrants facing their helpless Slovenian victims (Toroš 2011). 
TOROŠ

\section{Gradnik's sonnet "Vprašanje" ("Question”)}

Vprašanje $\mathrm{e}^{3}$

Kako si zgnetek me, nebeški Oče?

Čemu ta slast za neutešene sanje, ta strast krvi, mesa in duše rvanje, to srce žejno in nemirujoče?

Čemu mehkoba, ki se vdati hoče, in kljubovalnost in omahovanje, vrisk in obup, nevera in iskanje resnice, ko se v duši dvom grohoče?

Italsko sonce vlil si v moje žile: kri favnov in asiškega berača in Aretina in Giordana Bruna.

In si dodal še mračni srd Peruna, upornost sužnja, krutost osvajača in Črtomira kri in Bogomile.

The sonnet "Vprašanje" echoes the voice of Gradnik himself. The lyrical subject of the sonnet actually admits his double cultural origin - Slovenian and Italian. On the Italian side he describes some important Italian authors and thinkers (Francis of Assisi, Pietro Aretino, Giordano Bruno) as his ancestors. According to his words, he at the beginning of the $20^{\text {th }}$ century had very little knowledge of the Italian culture (Boršnik 2008: 292). We can therefore assume that his desire to uncover his own cultural heritage brought him to the world of the Italian art and science, which differed from the fascist culture in the Gorizia region. Gradnik identified himself with this "Renaissance" image of Italy.

In the sonnet, however, he also speaks about the Slovenian cultural tradition, which appears to be completely different from the Italian tradition,

3 Literal translation: Question // How did you mould me, Heavenly Father? / Why this passion for unfulfilled dreams, / this bloody delight, the struggle of meat and the soul, / this thirsty and unruly heart? // Why the softness, unwilling to give in, / and defiance and hesitance, / screaming and despair, disbelief and searching / for truth, while roaring laughter fills the soul? // You poured the Italic sun into my veins: / the blood of fauns and the beggar of Assisi / and of Aretino and Giordano Bruno. // And you added the murky rage of Perun, / the resistance of a slave, the cruelty of a conqueror / and the blood of Črtomir and Bogomila. 
even contrary to it. On the Italian side, it is of a positive nature and describes the joy of life and curiosity (the desire for improvement, innovation, overcoming the tradition), while on the Slovenian side it is of a dark nature, which is a consequence of the lack of freedom and of serfdom, which were present during the time of the formation of the Slovenian nation. The Slovenian ancestors actually lost their independence already in the $8^{\text {th }}$ century and regained it only in the year 1991. As a result, Gradnik's sonnet "Vprašanje" speaks about the epic poem Krst pri Savici (Baptism at the Savica), a work by the greatest Slovenian national poet France Prešeren (1800-1849). Gradnik's lyric subject identifies himself with the fate of the main characters of the poem, Crtomir and Bogomila. As a Pagan, Črtomir fights against Christianisation. He loses the battle. Moreover, this way he also loses his beloved, Bogomila, as she decides to spend the rest of her life in a monastery, practising Christian faith. She had pledged herself to the Christian God if the latter would save Črtomir's life. Črtomir accepts Bogomila's decision, converts to Christianity himself and becomes a priest. His baptising takes place at the Savica waterfall (in the central part of the present-day Slovenia), and hence the name of the poem Baptism at the Savica.

In the final part of the sonnet "Vprašanje", the author wonders how to balance both poles of his nature, how to achieve calmness, but he cannot find the answer to this question. In his later poems he never returns to his question. In the poetry of his later opus he does, however, once again restore the same image of the Italians, characteristic of his early works.

We can assume that Gradnik decided to refrain himself from his mother's cultural heritage due to the political situation. Gradnik's late collections of poems were actually published after Italy's capitulation in 1944, when the antiItalian and communist orientations were strongly present in the Slovenian territory. Refraining from his mother's cultural heritage was painful for Gradnik, which is evident in the poem "Mrtvi materi" ("To a dead mother") from the year 1938, in which he confesses his serious "sin" because of the "rebellion of the blood" (Gradnik 2002: 11-13). His passion for translating, which was most fruitful in the field of the Italian literature, must also have originated from his wish to achieve a mutual reconciliation of the two cultures, Slovenian and Italian.

From this point of view, Gradnik's translating of the Italian literature should not be understood in the sense of expressing support to fascism. For example, as late as in 1944, after Italy's capitulation, he began translating one of the most important works of the Italian literature, Dante Alighieri's Divine Comedy. Translating this work kept him busy almost until his passing away (Toroš 2005; Toroš 2013a). 
TOROŠ

On mentioning the forthcoming victory of the working class in Slovenian territory, another dichotomy of identity within Gradnik should be mentioned the social class dichotomy. He descended from a poor family, living in a rural environment, far from urban culture. But thanks to his talent and diligence, at an adult age Gradnik became financially well-off and entered the world of the bourgeoisie of the contemporary Kingdom of Yugoslavia. He was a lawyer by profession and in the last years preceding the Second World War he was appointed Supreme Court Justice in Zagreb in the present-day Croatia (Boršnik 2008: 449). Gradnik's photographs from the 1930s clearly reveal a significant gap between his public and private lives. On one hand, Gradnik can be seen wearing a wealthy bourgeois suit and, on the other hand, the photographs from the same period, taken by Gradnik himself, show Gradnik's family in Medana, in the Kingdom of Italy, doing farm work and wearing poor clothes. ${ }^{4}$

Gradnik's poetry remains loyal to describing a peasant man, peasant culture. Neither the motifs of the town, urban life and bourgeoisie nor the problems of the working class found place in his collections of poems. Gradnik's poetry was thus inconsistent with the predominant literary movement in Slovenian territory ${ }^{5}$ after the Second World War, socialist realism. Consequently, in the post-war period Gradnik remained on the verge of the Slovenian literary history. The reason for this also lies in the fact that he "flirted" with the Italian identity, which did not fit the image of a Slovenian poet. All this reflected in the rejecting of his poetry even in his native region, Goriška Brda. This must have been extremely painful for the poet, whose most beautiful and emotional verses in fact depict the village of Medana, Goriška Brda and the peasants of this area.

The reception of Gradnik among the Italians, Friulians and Slovenians

The reception of Gradnik as a half-Italian poet was different in Italy in the early 1940s. After the occupation of the Slovenian territory, especially of its central parts with Ljubljana, the Italian politics wished to Italianise Slovenian citizens through subtle assimilation. For this purpose, the so-called politics of the Slovenian-Italian cultural convergence was introduced. Gradnik fit perfectly

4 The photographs are part of the heritage of Alojz Gradnik, owned by his son Sergej Gradnik.

5 After the Second World War Slovenia was part of the Socialist Federal Republic of Yugoslavia. 
the purpose of the Italian politics of occupation (Godeša 1994: 113-118; Jan 1995: 422-428). He was of Slovenian-Italian descent, as he himself confessed in the sonnet "Vprašanje", and a translator of the Italian literature into Slovenian, a symbolic bridge bringing together the two cultures. Especially his comprehensive anthology of the Italian lyric poetry from 1940 came to widespread public attention, as it is reported to have been accepted even by the fascist leaders (N. N. 1941: 3). ${ }^{6}$

The Italian Slavists, who in this period acted in the spirit of the SlovenianItalian convergence and of the gradual assimilation of the Slovenian nation with the nation of the majority, the Italian nation, in their studies and newspaper articles created an image of Gradnik which was based on the abovementioned facts. This image was one-sided, as it had suppressed certain aspects of Gradnik's life and work. Among other things, it neither mentioned those Gradnik's poems which speak about the fascist suppression of the Slovenians, nor highlighted Gradnik's translations of Slavic, Germanic and non-European literatures, such as those of the Chinese lyric poetry (Toroš 2013a).

After the Second World War, when the "Italian" image of Gradnik was of no importance to the Italian politics any more, the Italian Slavists no longer dealt with Gradnik's life and work and the interest in the latter ceased after the Italian Slavists of the early $20^{\text {th }}$ century had retired or passed away.

In the first post-war period, Gradnik was thus exempted from both cultural circles which he felt part of, Slovenian and Italian. But this does not represent the epilogue of the story about Gradnik as an author at the linguistic, cultural and ideological crossroads. In the last decades, the Friulians have actually been increasing their consciousness about their own, Friulian identity. Consequently, an image of Gradnik as a poet with Friulian roots has recently been formed within their environment. This image of Gradnik sheds light particularly on those aspects of his life and work which are linked to the Friulian world. Hence the most well-known are those Gradnik's poems which speak about peasant life, with which the Friulians can identify themselves, as they have throughout the history been living in the immediate vicinity of and have been linked to Goriška Brda (Dapit 2008: 102-113). In 2005, a booklet with twelve of Gradnik's poems translated into Friulian was published (Gradnik 2005). Approximately the same number of poems translated into Friulian were also published in the proceedings of the international symposium on Alojz Gradnik in Udine in Italy (Ferluga Petronio 2008).

6 The anthology Italian lyric poetry is assembled in the chronological order. It starts with Saint Francis of Assisi and ends with Gradnik's contemporaries and thus forms, together with over eighty of selected authors a historical overview of the Italian poetry. 
TOROŠ

The Friulians not only draw attention to Gradnik - the poet, but also to Gradnik - the translator, as they have been highlighting his translations from Friulian literature. Gradnik actually learned Friulian already in his childhood, through contacts with his Friulian relatives, which around the year 1960 enabled him to publish some translated poems of the three Friulian poets, Novella Cantarutti, Lelo Cjanton and Dino Virgili (Toroš 2008; Toroš 2013a). The Friulians also draw attention to Gradnik's numerous testimonies of his Friulian relatives that he spent his childhood and youth with. Gradnik was actually particularly attached to his Friulian relatives on his mother's side, since he did not know his father's relatives. The interviews with Gradnik and other documented sources that have been preserved therefore reveal the idealised image of Gradnik's childhood, which he spent with his Friulian grandmother (Toroš 2013a).

In 2009, a collection of Gradnik's poetry translated into Spanish was published in Argentina, in Buenos Aires (Gradnik 2009). His poems had been translated by the Argentine writer and translator Julia Sarachu, with the help of a Slovenian language teacher from the University of Buenos Aires. Julia Sarachu has inherited a fondness for Gradnik's poetry from her Slovenian grandfather (Pišek 2011; Toroš 2013b). This can be understood as a symptomatic example of the reception of Gradnik among the Slovenians living abroad, from the end of the Second World War on. It seems that Gradnik's poetry is accepted in a different manner within the Slovenian communities abroad than in his homeland. The Slovenians abroad, especially the Slovenians living in Italy, regard Gradnik as an important symbol of the Slovenian culture through which they can identify themselves as Slovenians. The reason why the reception of Gradnik among the Slovenians varies may be due to the ideological gap which appeared after the Second World War. The borderline between Italy and Yugoslavia was actually also the border between capitalism and communism.

At this point it should be pointed out that after the Second World War the borderline between Italy and Yugoslavia was drawn exactly through Goriška Brda, which meant that a part of the Slovenians remained on the Italian side. Nowadays, they still belong to the administration of the Italian region FriuliVenezia-Giulia, which consists of provinces. The Slovenians from Goriška Brda who remained in Italy live in the Province of Gorizia (Slov. Goriška pokrajina), and there are also Slovenians living in the Province of Trieste (Slov. Tržaška pokrajina), with the city of Trieste as its capital, and in the Province of Udine (Slov. Videmska pokrajina), named after the town of Udine.

In the village of Števerjan (It. San Floriano), in the part of Goriška Brda which remained on the Italian side, a Slovenian primary school was named after Gradnik in the second half of the $20^{\text {th }}$ century. After the Second World War, 
another Slovenian primary school was named after Gradnik in the Municipality of Repentabor (It. Monrupino) in the Province of Trieste. On the other side of the border, in Slovenia, no schools have been named after Gradnik.

The poet Ljubka Šorli, who lived in the Province of Gorizia after the Second World War, dedicated a sonnet entitled To Alojz Gradnik, in which she wrote: "[Z]a nas je pesem tvoja kakor mana" (Šorli 1983: 136). I would particularly like to point out the fact that it was Šorli who wrote this sonnet, as she was considered to be a moral authority in the Gorizia region after the Second World War and has retained this role ever since. She gained such widespread recognition because of her suffering in the fascist period due to her relentless actions in favour of the Slovenians in Italy (Brecelj 2003: 99-108). Boris Pahor, an internationally renowned Slovenian writer from Trieste, a Nobel Prize nominee, also wrote about Gradnik as one of the important Slovenian poets (Pahor 1994: 11-25; 1997: 12).

The interest in Gradnik shared by the Slovenians living in Italy is still alive in the $21^{\text {st }}$ century. Dr. Fedora Ferluga Petronio, a Slovenian, living in the Province of Trieste, a lecturer of literature at the University of Udine, organised an international symposium on Gradnik in Udine in 2007. In 2013 she published a comprehensive and, in terms of the topics, diverse anthology of Gradnik's poetry translated into Italian, which was published by a Slovenian publisher in Trieste (Gradnik 2013; Toroš 2013b).

Gradnik's fate within the literary history has thus always been defined by his position at the linguistic, cultural and ideological crossroads. In different historical circumstances, Gradnik would most likely have accepted his dual national identity. But in the given historical circumstances, allowing a single national identity (Pertot 2007: 255-266), his inner drama could only have manifested on the level of his sonnet Question and on the level of translating the Italian literature into Slovenian. Gradnik's fate, which is being uncovered after more than fifty years after his death, must also have been shared by many an author of the first half of the $20^{\text {th }}$ century, who ended up at the European cultural, linguistic and ideological crossroads.

\author{
Ana Toroš \\ Ana.Toros@ung.si \\ Fakulteta za humanistiko \\ Univerza v Novi Gorici \\ Vipavska 13 \\ 5000 Nova Gorica \\ SLOVENIJA
}

'For us, your poem is like mana.' 
TOROŠ

\section{Sources and bibliography}

Boršnik, M. 2008. Pogovori s pesnikom Gradnikom. - A. Gradnik, Zbrano delo Alojza Gradnika [Collected Works], Vol. 5. Eds. M. Hladnik, T. Pretnar. Maribor: Litera, 251-484.

Brecelj, M. 2003. Pesnica Tolmina, Tolminske in trpljenja. - L. Šorli, Tolminske pesmi. Nova Gorica: Založba Branko; Ljubljana: Založništvo Jutro; Gorica: Goriška Mohorjeva družba, 99-108.

Čermelj, L. 1965. Slovenci in Hrvatje pod Italijo med obema vojnama. Ljubljana: Slovenska matica.

Dapit, R. 2008. Gradnikova Brda in odnosi s furlanskim svetom. - F. Ferluga Petronio, ed., Alojz Gradnik, pesnik Goriških brd. Trst: ZTT EST, 102-113.

Ferluga Petronio, F., ed. 2008. Alojz Gradnik: pesnik Goriških Brd: zbornik z mednarodnega simpozija na Univerzi v Vidmu (19.-20. aprila 2007): ob 125. obletnici rojstva in 40. obletnici pesnikove smrti. [Proceedings of the international symposium on Alojz Gradnik in Udine in Italy.] Trieste: ZTT = EST.

Gabršček, A. 1934. Goriški Slovenci II. Ljubljana: [self-publishing].

Godeša, B. 1994. Alojz Gradnik v času tuje zasedbe (1941-1945). - Primorska srečanja, 113-118.

Gradnik, A. 1986. Zbrano delo Alojza Gradnika [Collected Works] Vol. 2. Eds. M. Hladnik, T. Pretnar. Ljubljana: Državna zložba Slovenije.

Gradnik, A. 2002. Zbrano delo Alojza Gradnika [Collected Works] Vol. 3. Eds. M. Hladnik, T. Pretnar. Maribor: Litera.

Gradnik, A. 2005. Poesiis. Transl. Giorgio Faggin. Udin, Gurize, Pordenon: Clape culturâl Acuilee (Classics des leteraduris forestis 37).

Gradnik, A. 2009. La tierra desolada. Transl. Julia Sarachu. Buenos Aires: Gog y Magog.

Gradnik, A. 2013. Eros-Tanatos. Ed. and transl. Fedora Feluga-Petronio. Trst: ZTT.

Jan, Z. 1995. Zanimanje za slovensko književnost v obdobju fašizma. - Primorska srečanja, 422-428.

Kacin Wohinz, M. et al. 2000. Zgodovina Slovencev v Italiji 1866-2000. Ljubljana: Nova revija.

Kersevan, A. 2003. Kratek zgodovinski opis furlanske književnosti. - E. Costantini, ed., Dobrodošli v Furlaniji. Transl. Sara Boškin et al. Udine: Società filologica friulana, 215-254.

Križman, V. 2013. Furlanska identiteta: diplomsko delo. Nova Gorica: [V. Križman].

Marušič, B. 2013. Prispevek k poznavanju narodnostnih razmerv Brdih: ob 140-letnici briškega tabora. - D. Zuljan Kumar et al., eds., Brda in Brici: o ljudeh, zgodovini, jeziku, besedni umetnosti, stavbarstvu in rastlinstvu Brd. Dobrovo: Občina Brda, 107-128.

N. N. 1941. Alojz Gradnik kot prevajalec iz italijanščine. - Jutro XXII/139, 3.

Pahor, B. 1994. La contribution de la littérature slovène du Littoral - Trieste et Gorizia - à la culture de l'Europe centrale. - Anthropos, international issue, 11-25.

Pahor, B. 1997. Gradnikov Sonet o človeštvu: tržaško pismo. - Delo, 7. 8, 12. 
Alojz Gradnik, a Poet and Translator

Paternu, B. 1955. Petrarca pri Slovencih. - Naši razgledi 28. maja 1955. 246-248.

Pertot, S. 2007. V imenu očeta: Medgeneracijski prenos slovenskega jezika in identitete po moški liniji. - M. Košuta et al., eds., Živeti mejo. Trst: Slavistično društvo, 255-266.

Pišek, M. 2011. Intervju: Julia Sarachu, argentinska književnica in prevajalka: Slovenski pesniki na sloviti aveniji Corrientes. - Dnevnik, 30. 12.

Šorli, L. 1983. Alojzu Gradniku. - L. Šorli, Veseli Ringaraja: pesmi za otroke. Gorica: Katoliško tiskovno društvo, 136.

Toplak, C. 2011. Etnične skupnosti, narodi in nacije. - M. Lukšič Hacin et al., eds., Medkulturni odnosi kot aktivno državljanstvo. Ljubljana: ZRC SAZU, 15-19.

Toroš, A. 2005. Pregled knjižnih izdaj Gradnikovih prevodov. - T. Smolej, ed., Prevajanje baročnih in klasicističnih besedil: 30. prevajalski zbornik. Ljubljana: Društvo slovenskih književnih prevajalcev, 260-273.

Toroš, A. 2008. Seznami. - A. Gradnik, Zbrano delo Alojza Gradnika [Collected Works], Vol. 5. Eds. M. Hladnik, T. Pretnar. Maribor: Litera, 679-721.

Toroš, A. 2011. Podoba Trsta in Tržaškega v slovenski in italijanski poeziji prve polovice 20. stoletja, (Humanistika). Nova Gorica: Univerza.

Toroš, A. 2013a. O zemlja sladka: kamen, zrno, sok: Alojz Gradnik ter romanski in germanski svet, (Razprave in eseji, 65). Ljubljana: Slovenska matica.

Toroš, A. 2013b. Prevodi Gradnikove poezije v romanske jezike v 21. stoletju. B. Krakar Vogel, ed., Slavistika v regijah. Slovenski slavistični kongres. [Slovenian Slavic congress] Nova Gorica, 3.-5. oktober 2013. Ljubljana: Zveza društev Slavistično društvo Slovenije, 45-49.

Zadravec, F. 1999. Pesnik Alojz Gradnik (1882-1967). Ljubljana: Znanstveni inštitut Filozofske fakultete.

Župančič, O. 1917. Alojzij Gradnik. - A. Gradnik, Padajoče zvezde. Ljubljanski zvon. 47-49. 